\title{
Welcoming strangers!
}

\section{The responses of African pentecostal churches in London to Europe's migration and refugee crisis}

\section{Babatunde Adedibu ${ }^{1}$}

\section{Abstract}

The twenty-first century heralded a new phase in global migration trends which have led to the hyper diversities of cultures, ethnicities, social and religious idiosyncrasies in these contexts. The various economic, political, social and religious crises in the Middle East, North Africa and Africa that have taken place in the last sixty years (1960-2016) have contributed significantly to mass migration from these continents to Europe and America. However, it is pertinent to state that migration is not only to the West but multi-directional as many migrate within nations and continents in search of economic opportunities, safety and religious freedom. This development has generated diverse responses from various governments, organisations and individuals as well as non-governmental agencies on how to handle the migration crisis in these contexts. Despite the declining fortunes of Christianity in the West particularly England, the Church of England, Methodist, Catholic Churches and a host of others have lent their voices to giving the migration crisis a human face by the European governments. Nevertheless, the burgeoning stream of the Christian tradition in Britain which is the African Pentecostalism seems indifferent to Europe's migration crisis. Ironically, the African Pentecostal churches' proliferation is one direct gain of migration to Britain as the churches welcome their kith and kin from Africa and Africans that travel through North Africa to Europe. This paper aims to utilise the interpretative framework of Luke 10: 29 to explore the non-response of African Pentecostal churches in London to Europe's migration crisis. Likewise, this paper examines the biblical motif of who is thy neighbour and its implications in the intercultural engagement of these churches about the membership of these churches who are predominantly Africans.

Keywords: Migration crisis, African Pentecostal churches, London, Refugees, Migrants

\section{Introduction}

Globalisation of African Pentecostalism has been the focus of various scholars in the last 30 years in diverse contexts (Gornick 2011:3-19). Previous scholarships have

Babatunde Adedibu is the Provost of the Redeemed Christian Bible College, Nigeria. He holds a PhD in Missiology from North West University, South Africa. babatunde is also Associate Researcher with Cambridge Centre for the Study of Christianity. He can be contacted at babatunde.adedibu@rcbc.edu.ng. 
focussed on the social and religious idiosyncrasies of African Pentecostal churches within Africa and in Diaspora (Adedibu 2013:93-113;Adogame 2012:87;AsamoahGyadu 2005:22). Various aspects of the belief systems of African Pentecostal denominations has come under scrutiny by scholars such as piety, materialism, ritualisation, pneuma-centrism, wealth and health largely referred to as prosperity gospel (Adedibu 2015:207-233;Gerloff2010:311-312;Asamoah-Gyadu 2009;Ukah 2007:13). Various cross-events have led to the globalisation of African Pentecostalism which includes consigning of religion to the private space in the West and America. Likewise is thedynamic cultural shifts intricately connected to the increasing forces of secularisation and secular humanists.It seems more than mere coincidence of the growth of Pentecostalism across the globe particularly in the Global South with the declining influence of the church in public space in the Global North has led to the 'missionised' now missionaries to former heartlands of a mission to the rest of the world. The impact of such paradigmatic shift in missionising direction provides ample opportunities for intercultural discourse. These events have led to diverse expressions of Christianity from Africa within the British space which constitutes one of the several expressions across the Atlantic (Kwiyani 2014; Gornick 2011; Biney 2011).

The British Christian space particularly London has a definitive print of African Pentecostalism with the urbanisation of churches characterised by their distinctive socio-religious ethos to cope with the associated challenges of migration into a new cultural frontier by most members of these churches in the host context. Inadvertently these churches have created communities not only faith-related but also serve as social, economic and psychological anchors through various church programmes, ecclesiastical practices and rituals (Adogame 2016; Adedibu 2013; Sahar;2008).It seems a herculean task to have a comprehensive taxonomy of African Pentecostal churches in London largely due to the fissiparous nature of these churches. Some of the notable churches include transnational denomination like Redeemed Christian Church of God, Deeper Life Bible Church,Winners Chapel,Pentecost Church of God,New Covenant Church, Kingsway International Christian Centre (KICC), London Fire Church led by Pastor Jean Boscoand others to mention a few.

One of the major portals of the proliferation of Pentecostal churches in Britain is migration(Osgood in Goodhews 2012:110; Adedibu 2013:93-110).African Pentecostal churches recruitment and sustenance of their clientele is intricately dependent on economic migrants as a result of moral corruption and profligacy of African leaders that have rendered most of the nations in deplorable economic, social and developmental chaos; forced migration due to civil wars, famine or natural disasters not only in Africa but also from nations classified as developing world nations (Marshall 2001:84-85). 
Despite the multiplicities of expression of African Pentecostal churches in London, a major sociological hallmark identified by most scholars is the homogenous membership of these churches (Adedibu 2013: 405-423: Olofinjana 2010; Ukah 2009:104-132). However, the missionising ethos of these churches raises wider issues on the cross-cultural skills, contextual knowledge and the multicultural nature of urban cities like London raises wider issues regarding opportunities for cross-cultural mission and intercultural engagement which seemingly is neglected by African Pentecostal churches in urban cities in Britain particularly. The changing face of immigration and politicisation is pivotal in this discourse as noted below; this gives an overview of changes in the immigration policy within the EU particularly the United Kingdomabout the disposition of these churches to migrants from non-African states in the host communities.

\section{Migration and the changing face of the British space}

Migration is one of the emotive discourses in the contemporary societies. Migration has become a worldwide, multi-directional phenomenon which is re-shaping the Christian landscape. Various views have been expressed by previous scholarship (Freston 2010: 158; Hanciles 2008:123; Aldred 2006) as the multifaceted impact of migration not only in the receiving countries but the home countries of the migrants. One of such arguments particularly in the developing nations is the phenomenon of "brain drain" in which skilled workforce which is required for the development of the home countries attracted by the social and economic opportunities in the West thereby leading to continued underdevelopment of these nations (Adogame 2016; Adogame 2008:129-148). The inequalities in wealth between the Global North and the Global South where the migrants originate from might continue due to better economic indices, occupational mobility and better conditions of living as well as security. Nevertheless, some scholars have mooted the idea that brain drain has repository benefit of the sending nations. For instance, they argue that the intellectual appropriation and networking opportunities of the migrants in the receiving nations are harmonised in Diaspora which has to lead to the emergence and sustenance of institutional collaborations led by these migrants to their former homelands(Ahmadu 2009:109).

On the other hand, the receiving nations are very cautionedon migration which can change the social, political, economic and cultural tapestry of their society. International migration has reformed and changed the face of societies. Albeit, movement across borders have changed the face of societies from time immemorial. One of the cardinal impacts of this development is that London of today is a multicultural, multi-ethnic and pluralistic community. The 2011 census figures are reflective of the changing face of Britain. London has the largest population 
number (not percentage) of foreign-born in the United Kingdom, 36.7\% of London's population was foreign born (including $24.5 \%$ born outside of Europe) with 3,082,000 residents born abroad in 2014 (Rienzo and Vargas-Silva 2006).The uniqueness of the contemporary international migration trend is that it has global scope, social and pecuniary peculiarities characterise its significance to local and international politics. It is apt to observe that international migration is eroding the old dichotomy of the sending and receiving nation as many nations in the West and North America including Britain are experiencing emigration and immigration simultaneously.

Migration narratives in Europe seem heavily politicised with the rising interest across the social, political and religious divide. However, the issue of politicisation of migration in the UK, is more a 'bottom-up' process, with momentum generated by civil societies, interest groups and the media whilein a country like Switzerland it is more of "top-bottom" driven only governmental policy. It is imperative to note that irrespective of any state immigration policies inclusive of Britain are predicated on (a) claims of maintaining sovereignty of a state in its ability to regulate the influx of migrants across it borders (b) transnational challenge due to the ease of migration through travel and technological developments, many states are becoming security conscious of the implications of hosting migrants with dual nationalities due to rising tides of religious fanaticism and terrorism that are emerging across the globe.

The emergence of extreme right-wing, anti-immigrant political parties across Europe on social, religious and cultural diversities are very volatile in the European space. The rising tide of religious fanaticism such as Islamic extremism identified amongst second generation migrants from various countries who are now resident in Britain have further heightened public apathy towards immigration control. For instance, second generation Nigerians like Michael Adebowale and Michael Adebolajo both jailed for life for the killing of Fusilier Lee Rigby in Woolwich, London on the afternoon of 22nd of May 2013 are a prime example of radicalised second generation citizens of Britain. Extremismseems to be a transnational phenomenon since the 9/11 destruction of the World Trade Centre, Manhattan, New York and the Pentagon building, the Headquarters' of the United States Department of Defence. Similar events occurred in the United States (US) during the 2013 Boston Marathon when second generation US residents and Chechen brothers Dzhokhar Tsarnaev and Tamerlan Tsarnaev detonated home-made bombs during the Boston Marathon. Likewise was the Bastille Day attack in Nice, France on 15th of June 2016. Such religious extremism has accentuated the apprehension of anti-migration groups and public agitation in the West for the review of their immigration policies. It is apt to posit that the United Kingdom particularly Britain presents a case 
study to explore international migration trends during and after the Great Recession in the light of the changing face of the European population. The rresearch findings indicated below noted that:

"the number of foreign-born people in the UK increased in almost every year, although there were slight decreases in 1996, 2007 and 2010, while the number of foreign-born increased again from 2011 (fourth quarter data). Over the whole period analysed (1993 to 2014) the highest growth in the foreign-born population occurred between 2005 and 2008. This period coincides with the significant inflow of East European migrants following EU enlargement in 2004" (www.migrationobservatory.ox.ac.uk).

There is significant variation in the geographic distribution of migrants in the UK. In 2014, about half of the UK's foreign-born population was in London (36.9\%) and the South East (13.6\%). Wales, the North East and Northern Ireland have a low share of the UK's total foreign-born population, $2.3 \%, 1.6 \%$ and $1.5 \%$ respectively (Ibid). In comparison, the UK-born population is evenly distributed. In 2014, only 9.6\% of the UK born population lived in London (Ibid). London thus epitomises not only the economic heartbeat of the UK but also a confluence of economic, social, cultural and religious pluralities as a result of its diversities as it is the meeting point of migrants from different parts of the globe. The share of foreign-born people in the UK's total population increased by over 50\% between 1993 and 2014, i.e. from 7 to nearly $13.1 \%$; within the same period above, the share of foreign citizens rose from 3.6 to $8.5 \%$, while that of recent migrants increased from 1.4 to $2.7 \%$ (Lim:2016). There was a significant percentage increase in the share of foreignborn people in the UK's total population during the 2004-2008 periods (Ibid).

The immigration policies of the Britain over the years have changed significantly. Tony Blair, the former British Prime Minister administration which commenced in 1997 changed the face of British immigration policy. Blair's administration was a major shift from previous administrations in Britain through the recognition of the contributions of economic migrants to the economy which heralded the introduction of work permit and licensing scheme for employees to recruit outside the European Union. The resultant effect of this change in immigration policy during Tony Blair's dispensation was the largest single immigration wave in the history of the UK (Somerfield et al. 2009).

There has been an upsurge in international migration with the expansion of the European Union in 2004 due to her open access to migrants from the eight "Ascension" countries in May 2004. The net migration within a year (December 2003-December 2004) in the United Kingdom increased from 148,000 to 245,000 (Clark et 
al. 2014:2). Furthermore, at least seventy percent (2/3) of the increase in December 2003 to December 2004 are from the European Union (Ibid). Similarly, there was the integration of Romania and Bulgaria in 2007 in the EU. The Huge public outcry amongst the citizens of the old EU envisaging massive migration from Central and Eastern Europeans due to income differentials as a major motivation for migration. The perception was that these migrants might eventually settle permanently in the new host countries with possibilities of enjoying the social benefits of these states with associated adverse impacts on the host countries employment markets.

In response to the massive migration to the UK in 2004 from new member states of the EU was never envisaged by the government, this development led to significant changes in immigration policy framework. The altering of entrenched British multiculturalism policies occurred when July 7, 2005, attacks on London's transit system led to concerns about white and minority ethnic and religious groups (especially Muslims) leading segregated lives.

Similarly, the rising support in some quarters within the British populace for far-right political parties like the British National Party (BNP) was copious with the election of two BNP politicians to the European Parliament in June 2009, further intensified apprehension about attitudes toward diversity, immigration, and race.

In a motivated political response of the government due to dissenting voices from the media, interest groups averse to migration to the UK due to claims that UK resident workers were now competing in the labour market with the newcomers. The Bulgarian and Romanian migrants restricted their movements to the UK when their countries joined the EU in 2007.The introduction of the Seasonal Agricultural Worker Scheme (SAWS) was introduced for the low-skilled agricultural workforce targeted at the Romanians and Bulgarians to the exclusion of the same categories of workers from countries such as Ukraine, Belarus, and Moldova.

However, researchers noted these fears were unfounded because the majority of these migrants were temporary migrants in the receiving countries (Pollard et al. 2008). Overall, there was marginal increase in immigration from the EU8 (Czech Republic, Estonia, Hungary, Latvia, Lithuania, Poland, Slovakia and Slovenia) and EU2 (Romania and Bulgaria) within the EU15 population by approximately $1 \%$, with around $1.8 \%$ and $4.1 \%$ of the respective regions' population having moved into the EU15 (Czech Republic, Estonia, Hungary, Latvia, Lithuania, Poland, Slovakia, Slovenia, Romania, Bulgaria, Malta, Cyprus and Croatia) (Holland et al 20011). Nevertheless, the seemingly insignificant migration was heavily politicised by various interest groups.

Interestingly, international migration into the United Kingdom was very remarkable due to the prevailing state policies on migration which included the Skilled Migrant initiative to attract skilled workers into various sectors of the economy as well 
as the push and pull factors that are irresistible for economic migrants from Africa and Asia. Nevertheless, the migration trends within the period under consideration are not in no way comparable with figures from traditionally migrant countries like Australia, Canada and also United States (Clark et al.: 2). However, these were far less in comparison to the Spain and Italy, but above figures from Northern European countries like Germany, France and Scandinavian (Ibid).

Due to the UK commitment to the European Union treaties and law, the British government introduced the Points Based System (PBS). The uniqueness of the PBS is that it compressed the former immigration pathway of 80 work and study routes into five tiers (Devit 2012). The PBS which deals with economic and educational migrants from outside the European Economic Area (EEA) objectives were twofold (a) A political immigration policy to gain public confidence that the government was in control of migration to the UK (b) Creating opportunities for the best workforce skills requirements for the British sector. The compensatory gain of a skilled workforce to the UK contributes to the depletion of human and intellectual capital that can lead to continued underdevelopment of most countries particularly developing nations. Moreover, the explicit intention was to increase the average skill level of migrants from outside the EEA, and the scheme awards point to migrants for educational qualifications and English language ability as well as targeting a list of "shortage" of occupations. Nevertheless, despite various immigration policies introduced during the administration of David Cameron, the issue of immigration is hugely politicised characterised by claims of nationalism and being in control of the UK border.

However, various global events such as the Middle East crisis, Syrian fratricidal civil war and famine in various parts of the world have led to huge migration crisis in Europe. The European migrant crisis or European refugee crisis began in 2015, when a rising number of refugees and migrants made the journey to the European Union (EU) to seek asylum, travelling across the Mediterranean Sea or through Southeast Europe(Gideon;2015). The migrants notably leave their home countries as a result of protracted civil war, economic denigration, political and religious persecution originating from Western and Southern Asia and Africa. The number of forcibly displaced people worldwide reached almost 60 million at the end of 2014, the highest number in the past 70 years. Among these, 14.4 million were refugees, an increase of about 25 percent since the end of 2013 (United Nations High Commissioner for Refugees: 2015).The impact of the aforementioned is ahigh population of migrants in many European countries. A typical example is London which has almost $10 \%$ of the UK population living in the city but also has the highest migrant population in all regions of the UK. There is significant variation in the geographic distribution of migrants in the UK. In Table 1 below, London has the 
highest percentage of foreign born with a percentage of $36.9 \%$ while the South East is $13.6 \%$. Wales, the North East and Northern Ireland have a low share of the UK's total foreign-born population, $2.3 \%, 1.6 \%$ and $1.5 \%$ respectively.

\begin{tabular}{|l|l|}
\hline Region & $\mathbf{2 0 1 4}$ \\
\hline London & $36.9 \%$ \\
\hline South East & $13.3 \%$ \\
\hline East & $8.2 \%$ \\
\hline West Midlands & $7.6 \%$ \\
\hline North West & $7.6 \%$ \\
\hline East Midlands & $5.8 \%$ \\
\hline Yorkshire \& the Humber & $5.7 \%$ \\
\hline South West & $5.2 \%$ \\
\hline Scotland & $4.3 \%$ \\
\hline Wales & $2.3 \%$ \\
\hline North East & $1.6 \%$ \\
\hline Northern Ireland & $1.5 \%$ \\
\hline
\end{tabular}

Table 1: Distribution of foreign-born population, 2014; Source: Labour Force Survey, (Office of National Statistics)

The significant migrant's population in London is not only a by-product of Commonwealth ties but multiple reasons including the welfares' nature of the British government, the rising tides of social, political challenges across the globe. The Middle East and North Africa have been experiencing diverse political upheavals that have led to massive migrations. The on-going political turmoil in North Africa and the Middle East has led the emergence of refugees not only across North Africa but also Europe. However, a high percentage of migrants'domiciled in London highlighted have been politicised. In the wave of the referendum election for the continued membership of $\mathrm{UK}$ in the EU, the politicisation of immigration was a major headline in the mass media. Hall posits that "... more than five million people have been handed $\mathrm{EU}$ passports since 2009. All can enter the UK under freedom of movement rules. Official Brussels statistics show that in 2014 alone, 889,139 people were awarded passports by EU member nations. Most came from outside the EU, mainly from Morocco, Albania and Turkey" (Hall: 2016). Brexit campaigners said they provide fresh proof that Britain cannot control its borders unless the country quit the EU. Matthew Elliott, chief executive of the Vote Leave campaign, said: "this shows how little control we have over our borders while we stay in the EU. He argued that "the number of people coming 
to the $\mathrm{EU}$ increases each year and is becoming unsustainable. This level of migration puts a strain on our invaluable public services, as well as jobs and wages. The British people are right to be concerned" (Hall: 2016).

On the other hand, the social and economic implications of the rising tide of migration and refugees have shown that the case of Britain is one of the several examples in the European Union. It is quite a herculean task to ascertain the motivations for migration due to multiplicities of social, economic, political factors that are interconnected as most of the migrants are refugees, fleeing war and persecution in countries such Syria, Afghanistan, Iraq and Eritrea. United Nations High Commission for Refugees (UNHCR) stated that, $84 \%$ of Mediterranean Sea arrivals came from the World's top ten refugee-producing countries which are Syria (49\%), Afghanistan (21\%), Iraq (8\%), Eritrea (4\%), Pakistan (2\%), Nigeria (2\%), Somalia (2\%), Sudan (1\%), the Gambia (1\%) and Mali (1\%). Interestingly, $50 \%$ of the countries above of origin of the migrants are African states although this constitutes only $11 \%$ of the migration population of the 2015 figures released by the UNCHR.

In view of the fact that, this perhaps is the biggest human migration crisis in contemporary times, the public outcry for humanitarian support to ameliorate the plight of these migrants particularly those who travel across the Mediterranean Sea in dingy boats, overcrowded speedboats, canoes and so forth as smuggling gangs use more risky methods which have led to unprecedented number of deaths. According to the Wall Street Journal of May 31st, 2016, noted that over one thousand migrants died in the preceding week of the publication. The vivid images of capsizing boats, dead bodies washed ashore, and desperate attempts to rescue the perishing in the Mediterranean Sea are beamed live by the Television stations in Europe, frightening headlines of human casualties about migrants crossing the Mediterranean Sea are almost permanent features in tabloids and newspapers across the globe. Given the magnitude of the emotive nature of the migrants' experiences including human tragedy, various humanitarian initiatives not only through non-governmental agencies but also religious institutions of diverse strands across the Atlantic have emerged. The next section of this article examines the role of some Christian traditions in London particularly African Pentecostal Churches to Europe migration crisis.

\section{Mapping the responses of historic churches in comparison to African pentecostal churches in London to the Europe's migration crisis}

In the midst of the migration crisis in Europe, religious diversities are evident. Migration contributes to a more diverse Christian presence in Europe as well as to a more diverse religious landscape in many countries. Migration has always been 
part of the Christian narratives whether Protestant, Roman Catholic, Orthodox, or Pentecostal; it is not just a contemporary phenomenon but a major identity of the Christian faith. Most church fathers were at various times migrants due to secular or religious authorities' decision to exile some of them. For instance John Chrysostom (349-407), Bishop of Constantinople was banished to Caucasus (Brauer; 1971), but nevertheless managed to use his free time in exile to organise mission in Cilicia and Phoenicia. Athanasius (c. 296-373) was a Bishop of Alexandria for 45 years and spent a total of 17 of those years in exile (over five separate periods) (Barnes 1993:66). Others exiled included Maximus the Confessor (c. 580-662), Gregory of Nyssa (c. 334-394), and Cyprian, Bishop of Carthage (d. 258) amongst several others (Jackson 2011:2). Many Christian leaders and church members have had to face the same dilemma ever since, and some of these have chosen the hard migratory journey into exile (Ibid).

Christian migration has a biblical motif and featured in the early church as;

"Christians live in their countries, but only as aliens. They have a share in everything as citizens and endure everything as foreigners. Every foreign land is their fatherland, and yet for them, every fatherland is a foreign land. [...] They busy themselves on earth, but their citizenship is in heaven. [...] What the soul is in the body, the Christian are in the world. [...] Christians are scattered through all the cities of the world. [...] Christians dwell in the world but do not belong to the world" (Epistle of Mathetes to Diognetus cit in Richardson 1996:217-218).

Based on the foregoing.The concept of migration is synonymous with Christianity as the tradition affirms that its adherents are not permanently domiciled on earth but citizens of a celestial city. Through migration, minority churches in some countries are now an urban phenomenon in particularly in Europe in urban cities like London redefining the Christian landscape. These include, for example, the Protestant Churches in Europe in such countries in Italy and Ireland, the Roman Catholic Church in Sweden, the Orthodox Churches in France, and the Independent and African Pentecostal churches. Different ethnic (language) congregations of various denominations can be found in most cities like London. This further raises the urgent need to examine the responses of these Christian traditions particularly African Pentecostal churches to the migration crisis of Europe in the light of their missiological suppositions. The Christian worldview and sacred book are replete with positive notions to be hospitable to strangers which insist on the dignity of every human being. For instance, 'And if a stranger dwells with you in your land, you shall not mistreat him. The strangers who dwell among you shall be to you as one born among you.' (Leviticus 19:33-34) The strangers should be welcomed, and persons in need of protection should be provided 
with shelter by the Christian tradition. Welcoming strangers in any Christian space is part of the Christian commitment of servanthood.

From the experiential perspective as a researcher and faith leader in Britain, that magnanimity of Historic denominations towards refugees or asylum seekers is commendable; this affirms the dignity of every human being. Previous scholarships have identified the role of African Pentecostal churches in ameliorating the existential challenges of their members (Adogame, Magnus et al., 2013: 314;Adedibu 2013:110-117).Some scholars concluded that African Pentecostal churches in Diaspora are not only sacred spaces for rituals and religious practices but also community centres, socio-cultural hubs and identity negotiation in a new cultural frontier (Ibid). However, there is a dearth of research on the role of African Pentecostal churches in welcoming strangers outside their faith communities in the host communities where they are situated.

In response to the European migration crisis, the Council of Bishop of the Church of England passionately appealed to the British government in an open letter signed on the 10th of September 2015 by eighty-four (84) Bishops that the government should review its policy about Syrian refugees and increase it up to 50,000 in the next five years. The interesting twist in the open letter is that it is Christo-centric without a conversion agenda. They posited that:

"We [Council of Bishops] believe such is this country's great tradition of sanctuary and generosity of spirit that we could feasibly resettle at least 10,000 people a year for the next two years, rising to a minimum of 50,000 in total over the fiveyear period you foresaw in your announcement. Such a number would bring us into line with comparable commitments made by other countries. It would be a meaningful and substantial response to the scale of human suffering we see daily" (www.churchofengland.org).

While acknowledging the thoughtfulness and concern for the Syrian refugees, it is pertinent to note that granting refugee status to Syrian migrants is the aftermath of the crisis and not the solution. Nevertheless, such a clarion call gives the refugees ray of hope and opportunity for integration in the host society to rebuild their life and future. It is quite instructive to note that the Council of Bishops of the Church of England was not only prescribing an upward review of the British government policy on Syrian refugees, but they suggested that establishment of the National Welcome and Resettlement Board, mirroring the successful work of such boards created by Government in response to past refugee crises in the 1950s and 1970s. This suggestion was heeded by the governmentby the appointment of Rt. Rev. Paul Butler, the Bishop of Durham who posited that: 
"the Archbishop of York recently said that the current situation has rightly been described as a refugee crisis but it is also a time of opportunity for us as a country and for our wider continent. The opportunity before us is to rise above narrow self-interest, however, defined, and to embrace the highest parts of our humanity" (Ibid).

The clarion call to rise to the occasion by the Bishop of Durham was not in isolation of other Christian leaders within the historic denominations to assuage the sufferings of the migrants and give sanctuary and dignity to migrants in the receiving nations. The Rt Revd Steven Croft, Bishop of Sheffield of the House of Lords during the debate on the Report of the European Union Committee The EU Action Plan against migrant smuggling acknowledged that "throughout Britain, churches and faith communities are working in similar partnerships to build this ecology of care for refugees here and across Europe. Sheffield is the original city of the sanctuary, and the ideas have spread to many other places. The Sanctuary Movement works with local charities and local authorities to welcome and support those who need a place of safety" (https://churchinparliament.org).

Quakers raised similar humanistic concernsknew formally as the Religious Society of Friends about Europe's migrant crisis. In a press release by the Quakers on the 5th of September 2015 in London, they "urge the UK Government to welcome those desperately seeking a place of safety, in Europe, from the dangers in their countries. In this urgent situation it cannot be right to harden hearts against people who are struggling and dying on European soil and in the seas around us" (www. ekklesia.co.uk). The UK in the past have demonstrated its charitable disposition in some global events to avert severe human tragedies; the Quakers call is not a mere rhetoric but the acknowledgement of the British contributions to charitable causes and a subtle call for a humanitarian response to the migration crisis at their doorstep. Quakers noted that:

"we [Britain] have a tradition of sheltering those in danger, as we did with the Kinder transport, rescuing thousands of children from Nazi-occupied Europe so many years ago, and more recently when we welcomed refugees from countries including Afghanistan, Yugoslavia, Iraq, Bosnia and Kosova. It is time to open our hearts and communities again" (Ibid).

The migration crisis in Europe within the British space has been emotive in the light of the politicisation and desire of some political activist during the Brexit campaigns. In the light of the unfolding humanitarian crisis at the doorstep of Britain, a joint statement on the situation in Calais by the Baptist Union of Great Britain, the 
Church of Scotland, the Methodist Church and the United Reformed Church noted that the people and government of the United Kingdom need to exercise restraint. They noted that:

"as churches with members directly involved in assisting the people in Calais seeking sanctuary in the UK, we believe it is important that public debate is grounded in values of compassion and that facts make decisions. In recent weeks discussion has increasingly appeared to be based on the principle of self-interest. Our faith instructs us not to fear the stranger but to love our neighbour. We view the situation with growing alarm and anger. We are compelled to speak out on this issue. As Christian churches, we follow One who was himself a refugee and who demonstrated that all people have an inherent, God-given dignity" (www.churchofscotland.org.uk).

Interestingly, with pluralities of religious expressions in Great Britain due to its historicalCommonwealth ties as well as the ease of travel through technological developments and the forces of globalisation, the religious landscape of Britain has changed significantly in the last sixty years. Despite the diversities of expression of Christianity in Britain with the urbanisation of African Pentecostalism in various nooks and crannies of the country, this work was unable to identify any public statement on the unfolding migration crisis in Britain. The insular disposition of these churches raises wider concerns on the various scriptural references on welcoming strangers or the needy. This work makes use of the interpretative framework of Luke 10: 29 to explore why there is no public statement by African Pentecostal churches in London on Europe's migration crisis. Likewise, the next section examines the motif for the insular disposition of these churches of welcoming only Africans by these churches in London whether this is about recruitment and sustenance of their clientele base or religious prejudice.

\section{The biblical motif of who is thy neighbour (Luke 10:29) about the non-response of African pentecostal churches in London to Europe's migration crisis.}

Several biblical references are noted to mention the concept of 'neighbour' in the New Testament such as Matthew 22:34-40; Mark 12:28-31; Luke 10:25-28; Matthew 19:16-19; Matthew 5:43-48. It is thus imperative to ask whether these scriptural references have different approaches or are they different stories or incidents or at best contradictory? Two major terms are utilised in this storyline by Jesus that are quite poignant: 'neighbour' and 'Samaritan'. The concept of neighbour was first introduced by Jesus in Like 10: 27 as he asked his audience to "love God and their neighbour". In the synoptic gospel, the parable of the Good Samaritan is peculiar to Luke. Its peculiarity and the teachings embedded in it have stimulated many 
interpretations, usages and implications to contemporary society. Before looking at the implications of the parable, it is expedient to explore the some interpretations of the parable.

According to Welch (1999: 26), the parable of the Good Samaritan is so popular that non-Christians alike all over the world not only use but also apply it to different contexts. While most of the interpretations or contextual applications focus on its good neighbourliness, Kunhiyop's ethical dimension (2008:355) deepens the significant role of the physician, whom the Samaritan promised to pay at his return whatever extra sum he would have spent in addition to the amount he had deposited. He, therefore, charges contemporary African medical practitioners to take a cue from the physician rather than contemplate strike that can lead to death of patients. In any case, our interest in this present article lies in the good neighbourliness.

The hermeneutics of the parable took a cyclical form; starting as an allegorical interpretation to the historical and existential, after which scholars are now returning to its allegorical appeal. This has made Snodgrass (2000: 26) to say: "the interpretation of the parables has come full circle." Keesmat (2000: 26) is interested in the context of the parable. For him, "not only is the context of the parable authentic, but that that context actually provides the key to the parable's meaning." In other words, it will be difficult to understand the parable if the contextual equation is left out of it. The contexts of the parable have to do with the first century AD Palestine, and the Lukan context. While these contexts border on the mosaic and levitical laws on the one hand (and in fact, this paper is not concerned with that), on the other hands, it relates with the relationship between the Jews and the Samaritans. This second part forcefully brings out the theological rather than the allegorical import. Thus, Blomberg (1990: 276) argues that " $\mathrm{w} .25-37$ as a whole nicely conform to the Hebraic style of 'proem midrash' known as yelammedenurabbenu ('let our master teach us')." This is evident in Christ's turning the lawyer's question from the law to the love of God that should characterise human relationship as well. This love is meant to sunder racial and prejudicial barriers, to people we do not even know.

Thus, Jesus obviously does not commend the priest who is the first to arrive the scene and yet refuses to render help. For the priest, if he has contact with a corpse, he will surely not be qualified to participate in the wave offering. He may simply think that the wounded man is dead. The immediate implication will be that he and his family may go hungry for that time. For the Levite, Jesus also does not commend simply because the former believes that he is not under compulsion to help a Gentile. Though he comes closer than the priest to look at the victim, he also refuses to render any assistance. Jesus' commendation of the Samaritan and his command that he should be emulated come out of the fact that a Samaritan then was viewed as no better than swine, an animal highly prohibited by the Jews. It is 
then ironical that Jesus, being a Jew, would confront a fellow Jew such as a parable as this and command him to do what a "swine" did. The Samaritan gave first aid to the victim, saddled him on his ass, rushed him to a hospital, footed the immediate bill, deposited some more much and promised to pay any extra bill at his return.

The succinct implication within the context of this narrative hence is the quest for the redefinition of the concept of neighbour by the lawyer which with the Jewish culture is limited to the same people with social, cultural and religious subscriptions but the lawyer's motivation was more of the appraisal of Jesus' Jewish theological astuteness and Jesus' response was the parable of the Good Samaritan.Rather Jesus made use of a parable of the Good Samaritan. Jesus made use of several ironic tensions in the crafting of the storyline and characterisation such as the Levite, Priest, Samaritan, Jewish man and the contextual knowledge of the Jericho road during Jesus' day is comparable to associated challenges of migration experienced by migrants in charted territories as well as unconventional methods utilised by migrants in the face of social, political and religious upheavals in their home context. Just as the Jericho road was viewed as a very dangerous road, so also are many difficult sitautions that migrants pass through in attempting to cross borders.

Various views have been expressed on the Jesus motivations for the use of the Samaritan in this parable, but Crossan (1992:64-66) arguments seem conclusive as he posits that:

"If Jesus wanted to teach love of neighbour in distress, it would have sufficed to use the standard folkloric threesome and talk of one person, a second person, and a third person [to make his point]. If he wanted to do this and add in a jibe against the clerical circles of Jerusalem, it would have been quite enough to have mentioned a priest, Levite, and let the third person be a Jewish layperson. Most importantly, if he wanted to inculcate a love of one's enemies, it would have been radical enough to have a Jewish person stop and assist a wounded Samaritan. Since Jesus took none of these narrative options, his rhetorical goals lay elsewhere".

Furthermore, Crossan argues that:

" [w] hen the story is read as one told by the Jewish Jesus to a Jewish audience... this original historical context demands that the 'Samaritan' be intended and heard as the socio-religious outcast which he was... The whole thrust of the story demands that one say what cannot be said, what is a contradiction in terms: Good + Samaritan [In this way], the world is being challenged, and we are faced with polar reversal... [The hearers' world is being] turned upside down and radically ques- 
tioned in its presuppositions. The metaphorical point is that just so does the Kingdom of God break abruptly into human consciousness and demand the overturn of prior values, closed options, set judgments, and established conclusions" (Ibid).

Nevertheless, Jesus inverted the concept of Neighbour at the end of his narration and asked the Lawyer who thy Neighbour is? The implication of the inversion by Jesus in Luke 10:36 is that anyone who recognises and seizes an opportunity to help others is one' neighbour irrespective of social, cultural and religious subscriptions. Tolbert observed that "the introductory dialogue emphasises the beaten and robbed traveller: he is the neighbour we are to love, but the closing dialogue stresses the Samaritan: he is the neighbour we are to be.' So she concludes that the Lukan context of this story 'confuses the attempt to follow the narrative's logical movement and [to] clarify its elements"( Tolbert: 1979:60).

It may rather be suggestive in this context that the two personae, that is, the victim and the Samaritan be put into perspective. While the migrants are the victims because of their peculiar experience of being 'robbed' by emergency circumstances in their home countries, the African Pentecostal churches and their leadership should act like the Samaritan. As straightforward and logical this may sound, it is to be noted that the victim remained harmless to the keepers in the inn and the Samaritan as well.

It was quite obvious in the plot of the storyline that the Samaritan ought to have done several things considering the social-religious and cultural codes of Samaria to protect himself from the prospect of being injured by the evil eye (Longenecker 1999:92-108). Perhaps this might include some gestures of protection such as spitting to keep the injury at bay, or simply avoiding the half-dead man by feigning ignorance of the plight of the injured man. The Samaritan did not tow the lines of the Priest and the Levite as they acted in conformity with culturalcodes of evil; avoidance, in complete conformity with the cultural codes of evil-eye avoidance (Ibid, 104).

In the light of the absence of any public statement from any African Pentecostal churches in London on Europe's migrant crisis might be construed as an evil eye. It is quite intriguing to observe that some of these churches responded to previous humanitarian causes like the Haiti earthquake in which some of them contributed to the Haiti Appeal funds to alleviate the devastating effects of the earthquake, for instance, the Redeemed Christian Church of God, United Kingdom. However, given the marginal status of the majority of the members of these churches in a new cultural frontier, these churches are a repertoire of refuge to meet the existential challenges of their members. It thus behoves on one to note that despite the marginality of 
these churches regarding fiscal and human resources, influence and political clout within the British space are incomparable with the historic denominations which have been involved in humanitarian initiatives over time. While surprised by the internet findings that no African Pentecostal churches in London granted any position paper or press release on their activities to assuage Europe's migration crisis in London might be a matter of poor media visibility of these churches. I am acutely aware that Jubilee House for All Nations, Romford, London is actively involved in providing periodic support to European migrants in Soho Square, London.

However, 1 wish to posit that the lack of public visibility disposition of African Pentecostal churches to the plight of European migrants in London might be a by-product of suspicion in the light of the prevailing acts of terrorism identified amongst some of the migrant's nationalities in the receiving countries. However, such a stereotyping seems to be contrary to Jesus' commandment to love God and one's Neighbour in Luke 10:36. Nevertheless, 'love for neighbour' is ethically a commandment for Jesus' disciples as they are required to love God as a prior command (Matthew 25:35-36). It is thus incumbent on African Pentecostal churches in London that their Christian commitment is mandatory whether such neighbour by perception or circumstantial evidence might constitute a grave danger to the society. Any lessening of such a commitment can only ever be interpreted as an indication of inadequate discipleship, an indication of a lack of loving commitment to God.

The above school of thought is expressed in the Lausanne Movement evangelical Cape Town Commitment (2010) which recognises the inherent tensions generated for the individual non-migrant Christian by the ethical requirement to love God and love neighbour in the midst of hostile cultures: The Evangelical commitment might provide the much required learning curve for African Pentecostal churches in London as it asserts that:

"we encourage Christians in host nations which have immigrant communities of other religious backgrounds to bear counter-cultural witness to the love of Christ in deed and word, by obeying the extensive biblical commands to love the stranger, defend the cause of the foreigner, visit the prisoner, practise hospitality, build friendships, invite into our homes, and provide help and services.' (Leviticus 19:33-34; Deuteronomy 24:17; Ruth 2; Job 29:16; Matthew 25:35-36; Luke 10:2537; 14:12-14; Romans 12:13; Hebrews 13:2-3; 1 Peter 4:9)"(Ibid).

There is no doubt that African Pentecostal churches in London provide not only religious, socio- cultural spaces. Astonishingly, the pastoral care and concern for their members have not translated into missional opportunities within the diverse London population for intercultural engagement with non-Christians. This position is summarised in the conciliar statement on mission and evangelisation of World Council of Churches in Together towards Life (2013:Par 91) that: 
'[...] we are told [the scripture]: "do not forget to entertain strangers, for by so doing some people have entertained angels without knowing it." (Hebrews 13:2). Churches can be a place of refuge for migrant communities; they can also be intentional focal points for intercultural engagement. The churches are called to be one to serve God's mission beyond ethnic and cultural boundaries and ought to create multi-cultural ministry and mission as a concrete expression of common witness in diversity. This may entail advocating justice regarding migration policies and resistance to xenophobia and racism".

There is the urgent need for African Pentecostal churches in London to move beyond dualistic concepts of culturally dominant groups as hosts and migrants and minority peoples as guests. Migration is always about people, individuals, and communities, who should relate to each other through complex relationships. Migrants are people; with unique life stories, desires, aspirations, successes, and misfortunes. The divine economy can not dismiss the humanity and dignity of migrants in expressing love to one's neighbour irrespective of the religious, social or cultural orientation of the migrants. On the other hand, missiological inadequacies of African Pentecostal churches in cross-cultural engagements are mask under the guise of the insular disposition of their leadership as it is much easier to attract people of the same ethnic, race or culture for in Diaspora due to the associatedsocial, cultural and geographical discontinuities experiences of migrants in the host communities.

Conclusively, indifference to the fragility, suffering and weakness to the European migrant crisis raises theological issues on the African Pentecostal churches and their leader's compassion to perhaps one of the largest human tragedy in the twenty-first century. The inability of these churches and their leadership to be altruistic raises wider concerns with respect to their love for their neighbours. Unlike the Good Samaritan, who had insights beyond the issues of race, religion and nationality as well as regard for and devotion to the need of the wounded Jew is rather antithetical to the 'compassion code' of most African Pentecostal churches in London. The failure of these churches to understand the plight of the displaced European migrants in their true humanness depicts a lack of compassion which requires empathetic movement and action to assuage the sufferings of the European migrants.Unlike the Samaritan who did not act out of the fear of the evil eye, he acted in manners that are outside his cultural code as Samaritans and Jews had no positive dealings with one another (Jn 4). The lack of responsible movement of participation under the leadership of African Pentecostal churches in London at the expense of the displaced migrant's calls for concern while avoiding the curse of the evil eye.Compassion requires sensitivity to what is weak and or wounded, as well as the vulnerability to be affected by the other. 
While the case and attitude of the African Pentecostal churches in London have now been established requiring pragmatic retroactive cum proactive measures, looking forward, a more pressing opportunity offers itself in the case of America regarding President Donald trump' immigration policy suspending seven countries' entrance into the United States. The new theatre of defining neighbourhood and neighbourliness should be explored carefully in an ever changing world.

\section{References}

Adedibu B, A. "Checking' out of Nigeria for good! A critique of Nigerian Pentecostal Migrants turned Missionaries in London". Ilorin Journal of Religious Studies, Department of Religious Studies, University of Ilorin, ( forthcoming 2017)

Adedibu, B. A, God or Mammon? Piety and Probity: The Case of Britain's Black Majority Churches, Nigerian Journal of Christian Studies, Vol 11,(2015), 207-233.

Adedibu, B. A, Origin, Migration, Globalisation and Missionary Encounter of Britain Black Majority Churches, Studies in World Christianity. Vol. 17. (2013) No. 1, 93-113.

Adedibu, B.A Migration, Identity, and Marginalization: The Case of Britain's Black Majority Churches, Africana Journal of Religion, Vol 2, (2013),110- 117

Adogame, A, Gocalisation of African Christianity and the changing face of World Christianity. Paper presented at the maiden International Conference on African Pentecostalism organised by the Redeemed Christian Church of God and the Department of Religious Studies, University of Ibadan, held at the Redeemed Christian Bible College, Mowe, Ogun State, July 19th -21st July 2016.

Adogame, Afe, (2013), The African Christian Diaspora: New Currents and Emerging Trends in World Christianity, London: Bloomsbury Academic.

Adogame, Afe and Shankar, Shobana, (eds), (2013), Religion on the Move! New Dynamics of Religious Expansion in a Globalizing World, Leiden and Boston: Brill.

Adogame,Afe, 'I am married to Jesus!': The Feminization of New African Diasporic Religiosity," Archives de Sciences Sociales des Religions, 143 (2008): 129-148.

Ahmadu, Jacky Kaba, Africa's migration brain drain: Factors contributing to the mass emigration of Africa's elite to the West in Isidore Okpewho and NkiruNzegwu (eds), The New African Diaspora, (Bloomington, Indiana University Press, 2009)

Asamoah-Gyadu, Kwabena, Spirit, Mission and Transnational Influence: Nigerian-led Pentecostalism in Eastern Europe.Paper presented at the GloPent Conference, University of Birmingham, UK. 6th -7th February 2009.

Asamoah-Gyadu, Kwabena, (2005), African Charismatics, Current Developments within Independent Indigenous Pentecostalism in Ghana, Studies of Religion in Africa, Leiden: Brill Academic Publishers, 2005

Barnes, Timothy D., Athanasius and Constantius, (1993), Theology and Politics in the Constantinian Empire, Cambridge, Mass: Harvard University Press.

Beckford, Robert. Theology in the age of crack: crack age, prosperity doctrine and 'being there'. Black Theology in Britain 4(1): 2000, 15-16. 
Biney, Moses, (2011), From Africa to America: Religion and Adaptation Among Ghanaian Immigrants in New York, New York, New York University Press.

Blomberg, Craig (1990). Interpreting the Parables, Illinois: Inter Varsity Press.

Brauer, Jerald, ed. John Chrysostom Profile, (1971), The Oxford Dictionary of Church History, Philadelphia, Westminster Press.

Clark, Ken, Stephen Drinkwater, Catherine Robinson, Migration Economic Crisis and Adjustment in the UK, [Web]; http://ftp.iza.org/dp8410.pdf [Accessed 24th of August 2016]

Crossan, John, Dominic, (1992), In Parables: The Challenge of the Historical Jesus Sonoma: Pole bridge Press.

Freston, Peter, "Reverse Mission: A Discourse in Search of Reality," Penteco Studies, 9, no. 2 (2010): 158

Gerloff, Roswith, "The African diaspora and the shaping of Christianity in Africa: Perspectives on religion, migration, identity and collaboration," Missionalia 38, no. 2 (2010): 311-312.

Hanciles, Jehu, "Migration and Mission: The Religious Significance of the North-South Divide," in A. F. Walls and C. Ross, eds., (2008), Mission in the 21st Century: Exploring the Five Marks of Global Mission, London: Darton, Longman and Todd.

Jackson, Darrel, Imagine a Church without Migrants! A European Perspective, https://www. academia.edu/22812968/Imagine_a_Church_without_Migrants_A_European_Perspective [Accessed 24th of August 2016].

Keesmaat, Sylvia C. (2000) "Strange Neighbors and Risky Care," in The Challenge ofJesus' Parables, ed. Richard N. Longenecker, Grand Rapids, MI: W. B. Eerdmans.

Kunhiyop, Samuel W. (2008). African Christian Ethics, Nairobi: Hippo Books.

Kwiyani, Harvey, (2014), Sent Forth: African Missionary Work in the West, American Society of Missiology Series, (Maryknoll, Orbis,).

Lim, HK, Heuristics and Biases: Understanding Brexit from a Behavioural Economics perspective Part 1- The Attribute Substitution Heuristic, [Web]: http://thetroublewitheconomics.blogspot.com.ng/2016/08/heuristics-and-biases-understanding. html?view=flipcard [Accessed 24th August 2016]

Longenecker, Bruce W, “Until Christ is Formed in You”: Supra-human Forces and Moral Character in Galatians', CBQ 61 (1999), pp. 92-108

Marshall-Fratani,Ruth, 'Mediating the Global and Local in Nigerian Pentecostalism', in André Corten and Ruth Marshall-Fratani (eds.), (2001), Between Babel and Pentecost: Transnational Pentecostalism in Africa and Latin America, Bloomington: Indiana University Press

Olofinjana, Israel, (2010), Reverse in Ministry and Missions: Africans in the Dark Continent of Europe, USA, Author House, 2010

Osgood, Hugh, "The Rise of Black Churches," in Church Growth in Britain: 1980

to the Present, Ashgate Contemporary Ecclesiology Series, ed. David Goodhew, (2012),

Surrey: Ashgate,

Richardson, C.C.(1963), Early Christian Fathers, New York: Touchstone.

Rienzo, Cizenzia and Carlos Vargas-Silva, Migrants in the UK: An Overview, web: http://www.migrationobservatory.ox.ac.uk/briefings/migrants-uk-overview [Accessed 24th of August 2016] 
Richard N. Longenecker, (1999), Grand Rapids, MI: W. B. Eerdmans.

Sahar, G, (2008), "We're here to stay": African Migrant Workers in Israel and Back in Africa, Tel Aviv University Press,

Somerville, Will Dhananjayan Sriskandarajah, Maria Latorre,United Kingdom: A Reluctant Country of Immigration, [Web]: http://www.migrationpolicy.org/article/united-kingdom-reluctant-country-immigration [Accessed 24th of August 2016]

Snodgrass, Klyne R. (2000). "From Allegorizing to Allegorizing: A History of the Interpretation of the Parables of Jesus." In The Challenge of Jesus' Parables, ed.

Tolbert, Mary Ann, (1979), Perspectives on the Parables, Philadelphia: Fortress Press.

Ukah, Asonzeh, (2007), African Christianities: Features, Promises and Problems,Mainz, Germany, Institut für Ethnologie und Afrikastudien, Johannes Gutenberg-Universität,

Welch, John W. (1999). "The Good Samaritan: A Type and Shadow of the Plan of Salvation," Brigham Young University 38/2.

....., Bishop call on Prime Minister to provide "meaningful and substantial response" https://www.churchofengland.org/media-centre/news/2015/10/bishops-call-on-primeminister-to-provide-meaningful-and-substantial-response-to-refugee-crisis.aspx [Accessed 24th of August 2016].

....., Bishop of Sheffield speaks on Church Response to the migrant crisis, web: [https:// churchinparliament.org/2016/06/15/bishop-of-sheffield-speaks-on-church-responseto-the-migrant-crisis/] (Accessed 20th August 2016).

......, Cape Town Commitment, Section 5.B (The Lausanne Movement, 2010)

....., Churches speak out on migrant crisis, web:http://www.churchofscotland.org. uk/news_and_events/news/archive/articles/churches_speak_out_on_migrant_ crisis(Accessed 20th of August 2016)

......, Migrants in the UK Overview, http://www.migrationobservatory.ox.ac.uk/sites/files/ migobs/Migrants\%20in\%20the\%20UK-Overview_0.pdf [Accessed 24th of August 2016]

.Quakers make urgent call for safe paths for refugees Ekklesia Online Web: http://www.ekklesia.co.uk/node/22045 (Accessed 20th of August 2016) 